\title{
The Articulation of Massmedia and Social Media: Exploring civic movements in Portugal
}

Patricia Dias, José Gabriel Andrade

\section{Abstract}

Each time a new communication medium is introduced and reaches relative generalization, it creates new balances and articulations among the existing media, thus reconfiguring the whole mediatic and communicational landscape (Bolter and Grusin, 2000; Jenkins, 2006). In contemporary society, two types of media with totally different characteristics and operating logics coexist, articulate and converge among themselves - massmedia and social media - resulting in a new way of communicating, describes by Manuel Castells (2009) as mass-self communication.

Within public relations, several authors recognize a transition from asymmetric communication theories and models, in which organizations publicize information a strongly control their messages, to more symmetric conversation and dialogic models that are emerging as a consequence of PR professionals using social media as communication channels and tools (Kunsch, 2003; Solis and Breakenridge, 2009; Scott, 2010; Macnamara and Zerfass, 2012). Although most of these authors highlight the loss of control over their messages that organizations are undergoing, others explore the emergence of new power balances that are not necessarily symmetric or equalitarian (Edwards and Hodges, 2001; Coombs and Holladay, 2012; Dutta, Ban and Pal, 2012).

This paper explores civic movements as an example of the new articulations among massmedia and social media that emerging, as well as new power balances between the public, media and politic agendas (McCombs and Shaw, 1972). Using qualitative methods, this paper empirically explores the recent civic movements against austerity in Portugal, that culminated with the demonstrations "Geração à Rasca" ['Precarious' Generation] (12th March 2011) and "Que se lixe a Troika!: Queremos as nossas vidas" [Screw Troika! We want our lives back] (15th September 2012), discussing the articulation of massmedia and social media that was done both by citizens and communication professionals (PRs and journalists, as well the role 
played by each of these types of media in publicizing, mobilizing and in the social impact of these movements.

KeYwords: Public relations; Social Media; Massmedia; civic movements; communication.

\section{INTRODUCTION}

"Through word-of-mouth, in social media, truths that cannot be found on newspapers are heard."

Boss A.C., Friday (Good Job Now) (2011) [our translation]

Information and Communication Technologies (ICT) have undergone technological development and penetration at a speed without precedent in history. Generalized, frequent and intense use of technologies such as the computer, the mobile phone (or mobile devices) and the internet are related to several transformations in all social spheres, justifying Manuel Castells' (2005 [1996]) argument that we are witnessing a paradigmatic change of social model into a network society.

Data from October 2011 show that the internet penetration rate in Portugal has multiplied ten times in fifteen years (Marktest, 2011). According to more recent statistics, the internet penetration rate in Portugal is of 23\% for fixed access and 33,3\% for mobile access (ANACOM, 2013a), as smartphones' users have grown 4,8\% in the first semester of 2013 (ANACOM, 2013b). Social networks have stood out, along the profound economic and social crisis that Portugal is facing, the locus for debate of public opinion-mobilizing issues, mobilization and social contestation. Statistics from 2011 register only $35,8 \%$ of the Portuguese internet users as having profiles in social networks, among which 95\% has a Facebook account (Marktest, 2012). Thus, Facebook is clearly the most expressive and relevant social network in Portugal. Social media, because of their horizontal and collaborative nature, facilitate communication and interactivity, promote sociability and sharing, and enable the publicizing of contents and opinions to a wide audience. They also allow a collaborative agenda-setting of daily issues that is alternative to the one offered by the mass media. At the same time, there is an articulation of social media and mass media, as they are complementarily used by politicians, journalists and opinion-makers. Civic movements have been using social media not only as a publicizing and mobilization tool for their causes, but also as a way to get the attention of mass media, thus placing the issues they intend in the mass media agenda. This paper explores the articulation between mass media and social media, focusing on the civic movements against austerity in Portugal "Geração à Rasca" ['Precarious' Generation] and "Que se Lixe a Troika!" [Screw Torika!]. 


\section{Theoretical Framework}

This paper's theoretical framework combines contributions from media theory, organizational theory and sociology to explore the articulation of mass media and social media in the creation, publicizing, journalistic coverage and social impact of civic activism, studying in particular the Portuguese civic movements against austerity "Geração à Rasca" ['Precarious' Generation] and "Que se Lixe a Troika!" [ScrewTroika!]. These movements are approached as case studies, explored in the scope of a theoretical framework that combines, within media theory, Bolter and Grusin's (2001) concept of remediation and Castells' (2009) concept of mass-self communication; within organizational theory, contributions from several authors that advocate a paradigmatic change from asymmetric to symmetric organizational communication models, particularly in public relations (e.g. Kunsh, 2001; Cornelissen, 2011; Breakenridge, 2012); and, within sociology, Castells' (2012) approach to the social impact of civic movements, which the author argues that are potentiated by social media.

\subsection{Mass Media and Social Media: Differences, similarities and articulation}

The concepts suggested to describe the digital communication technologies that are currently integrated in our daily lives are several, as for instance web 2.0, new media and social media. Each of these concepts emphasizes different characteristics and is associated to concrete spatial, temporal, geographic and cultural contexts, as well as to specific technologies. However, they have in common the transition from analog to digital technologies and the change from a massified broadcasting logic to a personalized dialogical logic.

The designation social media emphasizes the promotion of sociability as the main feature of the media it describes. In a strict sense, it is understood as a synonym for social networks, applications whose aim is to promote communication, sociability and networking (creating and managing connections and relationships), thus making it easier to create, maintain and eventually intensify interpersonal and social relationships. In a broad sense, some authors also describe as social media applications whose contents are user-generated (e.g. blogs, wikis, YouTube, social bookmarking), underlining the contrast between the horizontal and collaborative structure of this type of media and the mass media, also designated as traditional or old media (e.g. print, radio, television), whose contents are unilaterally determined by the producers and broadcasted at the same time to a relatively passive audience. Postman (2011) defines social media alluding both to sociability and to content creation: 


\begin{abstract}
"What is social media? It is the involvement of the end user in the creation of online content, and the ease and variety of ways in which that user can create content, comment on it, add to it and share it, and create relationships with others who are doing the same." (Postman, 2011 [ao vivo]).
\end{abstract}

Kaplan and Haenlein (2010) suggest other definition that presents the Web 2.0 as a technological infra-structure that supports and enables the existence of collaborative applications that promote sociability and content sharing:

\footnotetext{
"[...] Social media is a group of Internet-based applications that build on the ideological and technological foundations of Web 2.0, and that allow the creation and exchange of User-generated content." (Kaplan e Haenlein, 2010: 61).
}

The growing proliferation of social media is described by Li and Bernoff (2008) through their concept of 'groundswell', which refers to the growing use of digital peerto-peer communication tools that allow users to obtain whatever they need from other users, collaboratively. This is, therefore, a generalized social phenomenon, with impact in all dimensions of society, and that consists in the expansion, intensification or 'swelling' of communication between people and between people and organizations in virtual spaces, where users are more active and participative.

Levinson (2009) criticizes the designation 'social media' by arguing that it does not describe the nature of this new type of media, as all communication media are social and promote, to some degree, sociability. However, his preference for the designation 'new media' can also be criticized with the same argument. In addition, the idea that, currently, there are technologies with a much more interactive and collaborative nature that the early world wide web (the author points to Twitter as an example), and that are therefore new new media, is unpractical and holds little meaning.

Manovich (2002), Livingstone (2002) and Flew (2008 [2002]) agree that the digital forma the main feature that distinguishes social media and mass media. Nonetheless, the authors also mention the articulation and convergence of both these types of media, referring the online presence of newspapers and television channels, for instance. The authors agree that the technological features of digital social media shape the format and content of the mass media they articulate with. Bolter and Grusin's (2001) concept of remediation also supports this claim. However, Livingstone (2002) suggests that the study of social media should focus more on their use and social impact than on their technological features:

\footnotetext{
"Many apparently novel traits of new media have been described, including hyperreality, virtuality, anonymity, interactivity and so on. However, we believe that new media can be characterized more usefully in term of, first, the particular ways that they are both
} 
the instrument and the product of social shaping, and second, their particular social consequences.[...] new media technologies both shape and are shaped by, their social, economic and cultural contexts" (Livingstone, 2002: 7,8).

To Jenkins (2006), media convergence also goes beyond the technological dimension, being therefore a cultural convergence driven by the users and not the technological features.

\begin{abstract}
"By convergence, I mean the flow of content across multiple media platforms, the cooperation between multiple media industries, and the migratory behavior of media audiences who would go almost anywhere in search of the kinds of entertainment experiences they wanted. Convergence is a word that manages to describe technological, industrial, cultural, and social changes [...] I will argue here against the idea that convergence should be understood primarily as a technological process bringing together multiple media functions within the same devices. Instead, convergence represents a cultural shift, as consumers are encouraged to seek out new information and make connections among dispersed media content." (Jenkins, 2006: 2-3).
\end{abstract}

Changes in the role of receivers, or audiences, os consumers, are early identified by Toffler (1980). The author proposed the term 'prosumer', combining producer and consumer, precisely to describe the fact that media consumers were becoming, due to digital technologies, able to produce and disseminate contents. This term has been adopted by other authors such as Castells (2004) and Tapscott (2008). In alternative, Bruns (2008) suggests 'produser': "[...] users of news websites who engage with such sites interchangeably in consumptive and productive modes (and often in both at virtually the same time)." (Bruns, 2005: 23).

But more important than distinguishing mass media and social media is understanding how these distinct-natured media coexist and articulate. Cardoso (2006) shows, when applying Castells' (2005 [1996]) concept of network society to the study of media in Portugal, that users tend to articulate different media - both mass and social media - instead of choosing just one type or the other. The author explains that digitalization contributes to the synthesizing of communication, both in its technological dimension (the reduction of different kinds of signal to binary code) and in content (there is a tendency to reduce and simplify digital messages - e.g. SMS, IM, microblogging). Furthermore, the author observes that users articulated digital and mass media according to their goals, needs and preferences. Drawing on these arguments, he suggests that we are witnessing the emergence of a new communicational model which he designates as synthetic networked communication:

"The communicational model generated in informational societies, where the model of social organization that prevails is the network, is the synthetic networked communication, a communicational model that does not replace previous models, but articulates them, producing new forms of communication [...]" (Cardoso, 2006: 212) [our translation]. 
Castells (2009) also argues that the articulation of mass media and social media leads to a new type of communication, mass-self communication. The author observes that the internet enables that two distinct types of communication - interpersonal and mass - occur simultaneously and mix, originating a new type of communication:

"I call this historically new form of communication mass self-communication. It is mass communication because it can potentially reach a global audience [...]. At the same time, it is self-communication because the production of the message is self-generated, the definition of the potential receiver(s) is self-directed, and the retrieval of specific messages or content from the World Wide Web and electronic communication networks is self-selected. The three forms of communication (interpersonal, mass communication and mass self-communication) coexist, interact, and complement each other rather than substituing one another. What is historically novel, with considerable consequences for social organization and cultural change, is the articulation of all forms of communication into a composite, interactive, digital hypertext that includes, mixes, and recombines in their diversity the whole range of cultural expressions conveyed by human interaction." (Castells, 2009: 55 [italic in original]).

This communication explores precisely the articulation of mass media and social media in the publicizing of civic movements and in the mobilization for demonstrations, as well as in their mediatic coverage and aftermath.

\subsection{Public Relations 2.0: How social media are changing public relations}

Social networks, that were initially a space for sociability within personal relations, are becoming more and more populated by organizations and thus becoming the place for professional and commercial interactions.

Along with broader-scope sociologic theories that relate digital technologies to social changes - such as Castells' (2005 [1996]) network society theory - several authors within public relations have argued that the growing use of social media as communication tool by organizations is associated with a paradigmatic change in organizational communication, that goes from asymmetric logic traditionally theorized by Grunig and Hunt (1984) to a symmetric logic (Kunsch, 2003; Solis and Breakenridge, 2009; Scott, 2010; Macnamara and Zerfass, 2012).

Two different approaches to the social impact of social media on public relations have been suggested: on the one hand, social media are considered new tools available to PR professionals that, because of their technological features, are changing professional practices; on the other hand, social media have been conceptualized as a contextual feature of contemporary society, thus associated to profound changes in organizational communication and in organizations themselves. 
Within the fist perspective, literature on how to communicate in each specific social media abounds, particularly focusing on Facebook (Levy, 2010; CIPR, 2012), o Twitter (Israel, 2009; Micek, Micek and Whitlock, 2009) and YouTube (Evans, 2010; Scott, 2010). Changes in the professional PR practices associated to the features of social media are identified, as for instance changes in the structure and style of press releases, the fact that answering stakeholders (and fast) has become mandatory, the fact that PR professionals must be available 24/7, and also the need for them to develop editing and publishing skills (Bratton and Evans, 2008; Hay, 2009; Brogan, 2010; Halligan and Shah, 2010; Wilcox and Cameron, 2010).

Within the second perspective, the main consequences associated to social media as a contextual element of contemporary society are the complexification of organizations and their context (Davis, 2009; Cornelissen, 2011) and the blurring of borders between organizations and their exterior (Miller, 2009; Cheney, Christensen, Zorn and Ganesh, 2011). Davis (2009) underlines that the increase in volume and speed of information in circulation results in organizations having to make much greater effort to succeed in getting the attention of their stakeholders in a stimuli-cluttered environment.

The empowerment alowed by social media, that enables consumers to become prosumers (Castells, 2005 [1996]; Tapscott and Williams, 2006) or produsers (Bruns, 2008) able to mass-self communicate their own content (Castells, 2009) represents a huge loss of control over their messages for organizations. Several authors elect this as the main challenge posed by social media to organizational communication (e.g. Postman, 2008; Qualman, 2009; Scott, 2010). This observation is the ground for the argument that organizational communication is changing from asymmetric to symmetric models (e.g. Kunsch, 2003; Solis and Breakenridge, 2009; Scott, 2010; Macnamara and Zerfass, 2012). Although several organizations still resort to asymmetric communicational practices and do not consider feedback from their stakeholders, this course of action is not suited to the needs, demands and preferences of those stakeholders. For instance, consumers trust more in the recommendations they get from their personal relations than in the messages from organizations (Qualman, 2009). Journalists also consider that most press releases are too long, irrelevant, and inconsiderate for their needs and preferences (Rossi and Azevedo, 2008). Thus, some authors argue that the changes needed in public relations in order to answer the needs, demands and preferences of their stakeholders go beyond professional routines. A change of mentality to a more horizontal and participative way of communicating is in order (Breakenridge, 2012; Theaker and Yaxley, 2012). However, Edwards and Hodges (2011) highlight that organizations are perpetuating their control in the communication process because, while starting dialogues with their stakeholders in apparently more horizontal relationships, they are collecting an unprecedented amount of data on consumer behavior through social media. Authors from a critical perspective point to social media as elements that reconfigure the power balance between organizations and their stakeholders, but do not necessarily result in a more 'balanced' or equalitarian balance (Coombs and Holladay, 2012; Dutta, Ban and Pal, 2012). 
Cornelissen (2011) suggests that the blurring between organizations and their exterior is matched by na approximation between diferente types of organizational communication such as marketing, public relations and internal communication. Miller (2009) also argues that the organizational communication strategy should be rethought in order to become grounded on integration and coherence among all communication types and channels. The challenge of obtaining attention in an information-overloaded and stimuli-cluttered environment demands coherence and consistency in organizational communication. Besides, it is required to articulate mass media and social media in order to build a strong image and a consolidated reputation.

Cheney et al. (2011) suggest the concept of integrated communication:

\begin{abstract}
"[...] 'integrated communication' is the notion that organizations, in order to establish their presence and legitimacy in the marketplace, must communicate consistently across different audiences and different media. By coordinating and aligning all messages from the organization (including visions, strategies, and identity themes), organizations pursuing integrated communication hope to create a unified impression of what the organization is and what it stands for." (Cheney et al., 2011: 126).
\end{abstract}

Kunsch (2003) states the need to develop a new communication mix that includes in na integrated way these new practices and communication tools. The author underlines the role played by public relations in organizational communication, arguing that it should be strategically integrated and interactive but focused on public relations in order to promote mutual benefits for the organization, its different stakeholders and society in general. Breakenridge (2008) coined the expression PR 2.0 that, although it apparently seems focused on the technological features of social media, is presented as a paradigmatic change in the mindset of the communication and PR professionals that goes beyond performance and routines. This change is grounded precisely in the transition from an asymmetric communicational logic to a more symmetric one, from publicizing to conversation.

These theoretical conceptualizations are important as a framework to look into the articulation of mass media, which follow an asymmetric communicational logic, and social media, with a more symmetric communicational logic. Also, the concept of public relations is pertinent to enframe the role of social activists that use social media to publicize their causes, to obtain notoriety and to mobilize, trying to set the agendas of mass media.

\title{
2.3. Civic Movements as locus for Articulation of Mass Media and Social Media
}

In the beginning of the $20^{\text {th }}$ century, the concept of social movements only encompassed the action of workers organized in labour unions. As the concept progressed as an object 
of study of the Social Sciences, mainly beyond the 60s, more definitions were suggested (Goss and Prudêncio, 2004). Most of them assumed a theoretical character, particularly in the work of Alain Touraine (1998), where social movements became the main object of study of Sociology. Although the concept has been intensely discussed in the last few years, there is no consensus among researchers (Goss e Prudêncio, 2004). Alberto Melucci (1999) considers the notion of 'civic movements' reductionist and prefers 'collective actions'. Within social movements theory, Maria da Glória Gohn (1997) states her own conceptualization of social movements as socio-political actions built by collective authors of different social classes, in a specific conjuncture of power relations in the civil society. For Gohn, these actions constitute a process of identity creation in collective non-institutionalized spaces, driving social change.

Facing a new generation of social and cultural conflicts, characterized by struggles about the goals of cultural production, education, health, environment and mass information, Touraine (1998) considers that associating the term 'resistance' to the protagonists of such actions is a form of social dominance against which one can argue drawing on values and generic orientations in society. In this sense, contemporary civic movements do not aim to create a perfect society, but struggle for the democratization of social relations (Goss and Prudêncio, 2004).

In contemporary society, resistance to established power is expressed in the defence of the subject:

"[...] New contestations do not aim to create a new type of society but to 'change life', to defend Human Rights, as well as the right to live of those who are threatened by hunger and extermination, and also the right to free expression and free choice of a lifestyle and a personal life story." (Touraine, 1998:262) [our translation].

In this sense, Ilse Scherer-Warren (2003) looks into collective action from the perspective of social networks which, among other things, play a strategic role of 'collective demon' and are the more expressive forms of contemporary political articulations, as world social forums, such as the anti-globalization, anti-crisis and peace movements.

In addition, the concepts of 'networked collectives' and 'networked movements' must be considered. According to Goss and Prudêncio (2004), the first refers to first instance communicational connections of several actors and organizations via internet, mainly to diffuse information, look for support and establish strategies for joint action. These collectives can be followed via the actors' presence in the internet. The latter refers to complex social networks that go beyond organization and connect them, symbolically, to social subjects and collective actors. Thus, the networked collectives are instrumentalized ways in which networked movements, in spite of not defining themselves as such, become constitutive parts of civic movements in the networked society (Castells, 2005 [1996]). This differentiation is needed because it amplifies Touraine's definition of social movements, 
according to which a collective social action is understood as bearing an identity, being directed to an adversary, and encompassing a project. In information society, networks enable a faster and wider information diffusion, connecting local and global initiatives. Thus, networks connect what Touraine distinguished as cultural movements and historic movements (Scherer-Warren, 2003).

Contemporary information society is facing an economic crisis. The first international financial crisis of the $21^{\text {st }}$ century began in September 2007, triggered by the bankruptcy of the Lehman Brothers Bank. In Europe, these changes had an impact in the sovereign debt crisis, which began to take place in 2009. The requests for external help coming from Greece (May 2010), Ireland (November 2010) and Portugal (April 2011), due to their incapacity to meet financial commitments, consolidated what is referred as the Euro Zone Crisis. This crisis, accompanied by the pressuring from north-American rating agencies (Moody's, Standard \& Poor's e Fitch), which have successively lowered the credit levels of European countries and organizations, including Belgium, Spain, Italy and France, grounded on speculation on possible failure to meet financial commitments, has led to the adoption of severe "austerity" measures from several European governments. The implementation of these measures, coordinated by representatives of the World Bank, The International Monetary Fund (IMF) and the European Central Bank in the countries receiving external help (Greece, Ireland and Portugal) set off, across Europe but mostly in these more vulnerable countries, sudden contractions of the GDP (superior to 3\%), exponential growth of unemployment (above 15\%), mass firings both in the public and private sectors, lowering of salaries and social benefits, raising of direct and indirect taxes, and severe overall consequences in the economy. This economic crisis differs because it occurs in a globalized environment, where networks enable much tighter connections and faster repercussions than in previous crises (Castells, 2011). The austerity policies have caused a 'collective rage' (Castells, 2011) that turned into the 'Indignados' [outraged] movement

\footnotetext{
"What was called the 'Indignados' Movement in Spain is a very altruistic movement, non violent, active, that follows a non-violence philosophy that attempts to rebuild social institutions by joining people, both in social networks online and in city squares across the country. This occurred during almost two months and completely transformed the social conscience and the political landscape in Spain. About 84\% of the Spanish support this movement." (Castells, 2011:14) [our translation].
}

Manuel Castells (2011) believes that, since the internet exists, people are on constant public debate, and they can go further in pursuing their goals because of permanent access to information, ideas and proposals in the public space, using technologies such as SMS, Facebook and Twitter to spread messages. Castells (2011) adds that the support from Labor Unions is fundamental to legitimize and amplify these emergent movements. For the first time in history, we have tools that help us build alternatives, designated as social 
networks (Cardoso, 2011). This new public space, a space between the network (the digital space) and the urban space, is a place for autonomous communication (Castells, 2012).

"[...] we have tools that allow us to react in terms of global movements. Since long ago we have been talking about global financial networks, commercial networks, information networks, and now we have social networks... In the countries were the crisis is more strongly felt, these tools are probably used to express oneself, to organize protests, to try to change something..." (Cardoso, 2011:55) [our translation].

The media coverage - from traditional mass media - of actions such as the 'Indignados' Movement has boosted the possibility for these to become known by wider groups and for obtaining support (or being rejected). Journalists are being called to act upon these movements - as professionals and as participants - via social media. Castells (2011) argues that the knowledge flows if the mass media fulfill their function and social role. Thus, receivers tend to search for alternative communication channels, using devices for interpersonal communication in mass communication processes, in order to establish alternatives to the agendas and coverage from the press, radio and TV channels (Cardoso, 2009). People watch television and read newspapers, but at the same time they communicate among themselves and question the messages they are getting from the mass media - are they true or not? - comparing that information with other they obtain online, in national and international news websites, in satellite TV channels, and in social networks (Eco, 2004; Cardoso, 2006). The technological development and the way users are appropriating the media lead to the coexistence of mass communication, social networks, and media that articulate them both. The main feature of this new way of communicating is its networked and connected nature (Cardoso, 2009). This new networked communication model is a media system where interactivity is the core of its organization. This model articulates a low interactivity system, where television plays a leading role, and a high interactivity system, based on the internet.

Our capacity to mass-self communicate (Castells, 2009) and to go from a mass communication to a networked communication (Cardoso, 2009) turns the social movements into a privileged locus to observe the articulation between mass media and social media. Besides, sharing information has been a human need long before the emergence of social movements:

\footnotetext{
"Human create meaning by interaction with their natural and social environment, by networking Their neural networks with the networks of nature and with social networks. Communication is the process of sharing meaning through the exchange of information. For society at large, the key source of the social production of meaning is the process of socialized communication. Socialized communication exists in the public realm beyond interpersonal communication. The ongoing transformation of communication
} 
technology in the digital age extends the reach of communication medium to all the social life domains in the network the same team That the global and local, generic and customized in an everchanging pattern" (Castells, 2012:6).

Social movements have been, throughout history, producers of new values and goals responsible for transforming social institutions in order to better represent and achieve them, resulting in new norms for the organization of social life (Castells, 2012). Networked communication media are nowadays crucial for social movements to achieve their purposes.

\section{Empirical Research}

\subsection{Methods}

This paper presents results from na empirical study that aimed to explore the way mass media and social media were articulated both by citizens and by communication professionals in the scope of the civic movements against austerity in Portugal, "Geração à Rasca" ['Precarious' Generation] and "Que se lixe a Troika!: Queremos as nossas vidas" [Screw Troika! We want our lives back].

Taking into account the theoretical framework we have presented as relevant for understanding the organization, expression and social impact of these civic movements, grounded on an articulation of Castells' (2009) mass-self communication concept with the organizational theory's argument that communication models are transiotioning from asymmetric to symmetric (e.g. Kunsh, 2003; Cornelissen, 2009; Davis, 2011; Breankenridge, 2012), we have adopted a qualitative and interpretivist empirical approach (Maxwell, 2005).

This study encompasses two methods: a) the ethnographic description of the main events associated to each of the movements studies, supported by documental analysis of mass media news and social media content, as well as in participant observation, as the researchers participated in these social movements; and b) interviews to relevant stakeholders, namely the organizers of these civic movements and journalists involved in their coverage (Berg, 2005).

\subsection{RESULTS}

\subsubsection{Description of the Studied Social Movements}

This section describes both social movements studied, "Geração à Rasca" ['Precarious' Generation] and "Que se lixe a Troika!: Queremos as nossas vidas" [Screw Troika! We want 
our lives back], articulating two different sources - a) news from mass media dating from the previous and following weeks to the protest demonstrations in which these movements culminated; and b) social media content about these movements (e.g. website, Facebook Page, posts and tweets) - with participant observation.

Concerning the "Geração à Rasca" ['Precarious' Generation] movement, the main documental sources considered were the initial Manifesto ${ }^{1}$ of the movement, the movement's official website ${ }^{2}$, and its official Facebook page ${ }^{3}$.

The "Geração à Rasca" ['Precarious' Generation] movement, before taking the streets, started in the social networks. Its emergence is associated to a concert of the band Deolinda where the song "Que Parva que Eu Sou" [I'm so silly/stupid], which tells the story of a generation of young people with big dreams and expectations but without the means to make them come true, caused strong identification. Social networks contributed to the quick dissemination of the song. Inspired by it, João, Paula and Alexandre took their first action on Facebook: the launch of the "Geração à Rasca" ['Precarious' Generation] protest.

"[...] 'It had to be quick, to follow the Deolinda trend - we sensed people were hungry for something that gave them a voice' explains Alexandre. But there had to be enough time for this idea to grow. 'We couldn't schedule it for the Carnival weekend, so we chose March 12th, in Avenida da Liberdade [Freedom Avenue] in Lisbon and in Praça da Batalha [Battle Square] in Oporto." (Cunha, 2011) [our translation].

Press and television followed the occurrence. In less than three weeks, thousands expressed their intention of attending the "Geração à Rasca" ['Precarious' Generation] demonstration. These people are the networked individuals (Cardoso, 2011). Offline, 300 mil demonstrators filled Avenida da Liberdade (Cavaleiro, Malta, Simões e Larguesa, 2011).

On April 15th 2011, the initial organizers of the movement founded the 12th March Movement (M12M). Other youngsters joined those first three activists in the whish to create a movement with the goal of "[...] turning each citizen into a politician." [our translation] and promising to be "[...] an active voice promoting and defending democracy in all spheres of our lives." [our translation] (Jornal de Notícias, 2011).

Concerning the "Que se lixe a Troika!" [Screw Troika!] movement, the main documental sources considered were the movement's official blog ${ }^{4}$ and official Facebook page $^{5}$. The call for this movement appeared as an event on Facebook, and the mass media covered this action.

\footnotetext{
1 http://geracaoenrascada.wordpress.com/manifesto/.

2 http://www.movimento12m.org/.

3 https://www.facebook.com/movimento12m?fref=ts

4 http://queselixeatroika15setembro.blogspot.pt/

5 https://www.facebook.com/pages/Que-se-Lixe-a-Troika-Queremos-as-nossas-Vidas/177929608998626
} 


\begin{abstract}
"There are almost 47 thousand names enrolled to go from Praça Fontana [Fontana Square] (in Picoas) to Praça de Espanha [Spain's Square] on Saturday, the $15^{\text {th }}$, at 5 p.m.. Currently, a total of 94.359 people have pushed Facebook's 'I'm going' button, 11.709 more than on Tuesday. Thirty cities have joined the demonstration. These numbers are much higher than the $12^{\text {th }}$ March demonstration, which tokk nearly 300 mil to the streets." (Leça, 2012) [our translation].
\end{abstract}

The journalists were able to make a connection between the two movements. Also, the coverage from the mass media made the interest in participating in this protest grow. Austerity models have caused a collective rage (Castells, 2011) that was expressed in this pacific march from Praça Fontana to Praça de Espanha. However, people demonstrating decided to take the protest to São Bento, the official residence of the prime-minister, trying to show their outrage closer to the Portuguese government. Mass media were there ready to broadcast live. The violence shown by some demonstrators and by the Police filled the screens worldwide as a demonstration of the outrage of the Portuguese. Besides Lisbon as its main stage, the demonstration had repercussions in 24 other Portuguese cities, although with less expressive participation. In addition to this significative offline adherence, there was heavy traffic on social media and the demonstration was covered by several national and international mass media.

We highlight the photo presented on Figure 1, where a young woman embraces a policeman. Captured by the photojournalist João Manuel Ribeiro from Reuters Agency, this photo was heavily disseminated by the mass media as symbol of a pacific alternative to violent protesting. The agenda-setting of this content by the mass media, and the latter coverage of this story, with interviews to the protagonist Adriana Xavier in journalists pieces from the private channel SIC, had repercussions on the social media, where the photo was exhaustively shared and commented. 


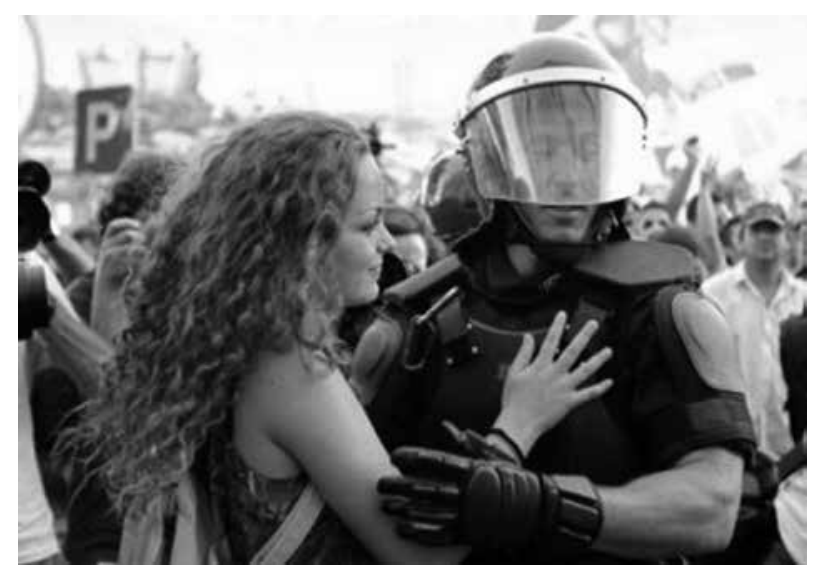

Figura 1: Adriana Xavier hugs a policeman during the demonstration "Que se lixe a Troika!" ["Screw Troika!"] in Lisbon. Source: Reuters/José Manuel Ribeiro (2012).

Adriana herself recognized in an interview that, besides the feelings and emotions that drove that action, she hugged the policeman also because she had seen similar photos from other conflicts and social movements (Viana and Ramos, 2012), thus revealing the influence of the agenda-setting made by mass media. On the other hand, the way this photo was appropriated by the social movements themselves, and also by the citizens, who shared it and commented on it, shows the constant and dynamic articulation between mass media and social media.

\subsubsection{Findings from the INTERVIEWS}

The interviews included 10 interviewees, 5 journalists involved in the coverage of at least one of the movements studied and 5 activists involved in the organization of at least one of them. Some of the interviews were conducted face-to-face while others were answered via email or Facebook, between December 2012 and January 2013. Although we tried to obtain a greater number of answers, that was impossible in the time framework established for this research. Although our initial intention was conducting indepth interviews, scheduling difficulties forced us to adopt a shorter and more structured approach, applicable via email or Facebook. Thus, we chose to organize the interviews' transcriptions on analysis grids.

One of the questions addressed in the interviews was the role played by social media in the social movements studies. Both activists and journalists agreed that social networks 
played a fundamental role. The activists highlighted the role that social media played in the publicizing of the movements and in mobilizing people for the demonstrations they culminated in. "The protest 'Geração à Rasca' ['Precarious'Generation] was, at the same time, a scream of hope and outrage that happened in a decisive moment of the political and social Portuguese life." (Activist 3) [our translation]. On the other hand, journalists point out the role of social media in the debate of the issues addressed. Journalist 3 refers that "[...] social networks were the co-generators of a civic conscience that many thought was lost." [our translation]. The movements' presence on the social networks was determinant for the actual turnout in the streets and also for getting the mass media attention:

\begin{abstract}
"Social networks, and particularly in the case of the 'Geração à Rasca' ['Precarious' Generation] movement, Facebook, played a very important role as an autonomous communication medium where the interaction between those organizing the protest and those invited to attend was possible without intermediaries. But the success of the 'Geração à Rasca' protest was due, too, to the way all mass media potentiated what was happening on Facebook. The 'likes' and the attendance confirmations were an indicator, measurable, quantitative. But those numbers did not represent the society in its whole nor the real reach of this initiative, born on the social networks. It does not allow the qualitative interpretation of that reach nor of the consequences it had outside of the social network. In the case of the 'Geração à Rasca' protest it is evident that it represented the beginning of a new way to make politics, it was the beginning of something that we are not sure yet what it is. But we do know there are more people involved, both politically and civically, creating more events on the social networks and outside of them, contesting more, talking and thinking more about policies and people's problems in a more organic and democratic way." (Activist 1) [our translation].
\end{abstract}

Another question compared the mass media coverage with the contents circulating on social media. Opinions are divided in this matter as activists claim that social networks are a free space for citizens to express themselves and emphasizing thae fact that these media allow "[...] the voice of citizens to go further [...]" (Activist 2) and journalists stating that the mass media coverage is more rigorous and objective, as it includes all parties involved in the issue. However, Journalist 1 refers the influence of newsworthiness criteria that is inherent to journalistic routines on the coverage of these events, recognizing that social media content was framed in the news coverage offered by mass media:

"The contents circulating on social networks are naturally biased, as they are shared mainly by supporters of those movements. Mass media did an exhaustive coverage, as it should, taking into account that we were dealing with unprecedented events. It only failed in the excessive coverage of violence. In its eagerness to present news, by reporting 
the violent events, it often forgot the real news, the purpose of the demonstrations." (Journalist 1) [our translation].

"The advantage of the social networks is allowing communication without filters from the traditional mass media, which is an advantage but can also be a disadvantage. Mass media helped to potentiate the participation of people in the protest and dealt with the issue of precarity in a way they hadn't done before. The fact that this was a new way of making politics, organic, non-hierarchical, nor submitted to parties, helped in getting the interest from mass media to cover the protest. Actually, and as paradoxical as this may seem, after the demonstration there was this silencing of the proposals and ongoing activities from all the people across the countries that had organized this demonstration." (Activist 1) [our translation].

When questioned about which kind of media had greater reach, both activists and journalists agree that mass media, among which several of the interviewees highlight television, are still the main source of information for most people. Some interviewees recognize that social media may occasionally reach a high number of receivers. As in the case of these social movements, but believe that the main reference for information are still the mass media.

Exploring the role that each type of media pays as public opinion influencer, both activists and journalists also chose mass media. Social media are seen as a place of opinion expression, and not of opinion influencing. From the interviewees point of view, people resort to social media to comment and share whaen they already have an opinion, and prefer mass media when they need information. Journalist 5 claims that "Social networks still play a merely complementary role." [our translation]. Journalist 1 emphasizes the fact that some mass media are more influential in the public opinion than others, depending on its credibility and/or on the opinion leaders involved. Activist 4 claims that "There are different and complementary publics both for the mass media and the social media." [our translation].

Finally, when questioned about the credibility of each of these media, both journalists and activists agreed that the mass media still have greater credibility, pointing out that "[...] social networks are not mass media." (Activist 3) [our translation].

\section{Concluding Remarks}

The information structure, today, is grounded on an essentially technological logic. Information is its raw-material. These technologies act upon information, they're not just information to act upon technology as it was the case in previous technological revolutions (Castells, 2005). Turning world events into news, communicating and acting, all come 
into being in the process of technological ordering. Technological information - texts, sounds, drawings, photographies and videos created and distributed via the most diverse technological instruments is nowadays common everywhere (Castells, 2005; Ilharco, 2003; Cardoso, 2006). Information is in sight and at hand, we use it, we instinctively and intuitively base on it to accomplish the most diverse tasks and activities. In a transparent way, what today models our actions are the computer and the information networks.

The articulation of new and old media results in the information sources of contemporary society. Contemporary society is shaped by the coexistence, articulation and convergence of two types of media with completely different characteristics and logics - mass media and social media - that leads to a new type of communication, mass-self communication (Castells, 2009). This phenomenon can be observed in the communication actions concerning the Portuguese social movements "Geração à Rasca" ['Precarious' Generation] and "Que se lixe a Troika!" [Screw Troika!]. The articulation of sending information via social networks was crucial for the offline events, an example of how, in public relations, the communication models are going from asymmetrical to symmetrical, becoming more conversational and dialogical, as a consequence of social media use as a tool and channel for public relations (e.g. Kunsch, 2003; Solis and Breakenridge, 2009; Scott, 2010; Macnamara and Zerfass, 2012).

This paper argues that the articulation of mass media and social media by citizens and professionals, as well as their role in the publicizing, mobilizing and social impact of social movements, is resorting to public relations practices based on symmetrical and conversational communicational models, thus being more successful in getting the attention of both social networks' users and journalists and also in driving further sharing.

\section{REFERENCES}

ANACOM (2013a). Informação Estatística do Serviço à Internet: 1º Trimestre de 2013. [online] http://www.anacom.pt/render.jsp?contentld=1162197\#n3

ANACOM (2013b). Informação Estatística do Serviço Móvel: $1^{\circ}$ Trimestre de 2013. [online] http://www.anacom.pt/render.jsp?contentld=1162118

Berg, B. (1989). Qualitative Research Methods for the Social Sciences. Boston: Ally and Bacon. Bratton, S. e Evans, D. (2008). Social Media Marketing: An hour a day. New Jersey: John Wiley \& Sons.

Bolter, D. e Grusin, R. (2000). Remediation: Understanding new media. Cambridge: The MIT Press.

Breakenridge, D. (2008). PR 2.0: New media, new tools, new audiences. New Jersey: FT Press. Breakenridge, D. (2012). Social Media and Public Relations: Eight new practices for the PR professional. New Jersey: FT Press.

Brogan, C. (2010). Social Media 101: Tactics and tips to develop your business online. New Jersey: John Wiley \& Sons. 
Bruns, A. (2008). Blogs, Wikipedia, Second Life, and Beyond: From Production to Produsage. New York: Peter Lang.

Cardoso, G. (2006). Os Media na Sociedade em Rede. Lisboa: Fundação Calouste Gulbenkian.

Cardoso, G. (2009). Da Comunicação de Massa à Comunicação em Rede. Lisboa: Porto Editora.

Cardoso, G. (2011) "A falência do interesse próprio e o poder da pertença". In Afermath As culturas económicas da crise em debate. Editora Mundos Sociais. Lisboa.

Castells, M. (2004). A Galáxia Internet: Reflexões sobre internet, negócios e sociedade. Lisboa: Fundação Calouste Gulbenkian.

Castells, M. (2005 [1996]). A Era da Informação: Economia, sociedade e cultura, Vol.1 - A Sociedade em Rede. Lisboa: Fundação Calouste Gulbenkian.

Castells, M. (2009). Communication Power. Oxford: Oxford University Press.

Castells, M. (2011) "A crise global não é global e as culturas económicas alternativas". In Afermath As culturas económicas da crise em debate. Editora Mundos Sociais. Lisboa.

Castells, M. (2012). Networks of Outrage and Hipe. Cambridge: Polity Press.

Cavaleiro, D., Malta, J.C., Simões, B. e Larguesa, A. (2011). "'Geração à rasca' leva 300 mil manifestantes à Avenida da Liberdade". Jornal de Negócios [online] http://www. jornaldenegocios.pt/economia/detalhe/quotgeraccedilatildeo agrave rascaquot leva 300 mil manifestantes agrave avenida da liberdade.html

Cheney, G., Christensen, L., Zorn, T. e Ganesh, S. (2011). Organizational Communication in an Age of Globalization: Issues, Reflections, Practices. Illinois: Waveland Press.

CIPR (2012). Share This: The social media handbook for PR professionals. New York: Wiley. Cornelissen, J. (2011). Corporate Communication: a Guide to Theory and Practice. London: Sage.

Cunha, P. (2011). "Um desempregado, um bolseiro e uma estagiária inventaram o Protesto da Geração à Rasca". Público. [online] http://www.publico.pt/sociedade/noticia/umdesempregado-um-bolseiro-e-uma-estagiaria-inventaram-0-protesto-da-geracaoa-rasca-1482270

Davis, M. (2009). The Fundamentals of Branding. Lausanne: AVA Academia.

Eco, U. (2004). "Il pubblico fa male alla televisione?". Espresso Online.http://www.espressonline.it/eol/free/jsp/detail.jsp?m1s=0\&tm2s=null\&tidContent=479137\&tidCategory=4789

Edwards, L. e Hodges, C. (2011). Public Relations, Society and Culture: Theoretical and empirical explorations. London: Routledge.

Evans, L. (2010). Social Media Marketing: Strategies for Engaging in Facebook, Twitter and Other Social Media. Indianapolis: Que Publishing.

Flew, T. (2008 [2002]). New Media: An Introduction. Oxford: Oxford University Press.

Gohn, M. (1997) Teorias dos movimentos sociais. Paradigmas clássicos e contemporâneos. São Paulo: Loyola.

Goss, P e Prudêncio, K. (2004) 0 Conceito de Movimentos Sociais Revisitado. Revista Eletrônica dos Pós-Graduandos em Sociologia Política da UFSC Vol. 2, nº 1 
Grunig, J. e Hunt, T. (1984). Managing Public Relations. New York: Holt, Rinehart \& Winston.

Halligan, B. e Shah, D. (2010). Inbound Marketing: Get Found Using Google, Social Media and Blogs. New Jersey: John Wiley \& Sons.

Hay, D. (2009). A Survival Guide to Social Media and Web 2.0 Optimization: Strategies, Tactics and Tools for Succeeding in the Social Web. Texas: Dalton Publishing.

Ilharco, F. (2003). Filosofia da Informação: Introdução à Informação como Fundação da Acção, da Comunicação e da Decisão. Lisboa: Universidade Católica Portuguesa Editora.

Israel, S. (2009). Twitterville: How Businesses can Thrive in the New Glonal Neighborhoods. New York: Penguin Group.

Jenkins, H. (2006). The Convergence Culture - Where Old and New Media Collide. New York: New York University Press.

Jornal de Negócios (2012). "Organizadores da 'Geração à Rasca' criam 'Movimento 12 de Março'". Jornal de Negócios [online] http://www.jn.pt/Paginalnicial/Nacional/Interior. aspx? content id=1831152

Kaplan, A. e Haenlein, M. (2010). "Users of the World, Unite" The Challenges and Opportunities of Social Media". Business Horizons, vol. 53, n. ${ }^{0}$ 1. Amsterdão: Elsevier, pp. 59-68.

Kunsch, M. (2003). Planejamento de Relações Públicas na Comunicação Integrada. 4.ed. São Paulo: Summus.

Leça, R. (2012). "Portugal vai mandar a Troika 'se lixar' e não está sozinho". TVI24 online. [online] http://www.tvi24.iol.pt/economia/manifestacao-que-se-lixe-a-troika-troikaausteridade-crise-agencia-financeira/1374421-1730.html

Levinson, P. (2009). New New Media. Massachusetts: Allyn \& Bacon [edição Kindle].

Levy, J. (2010). Facebook Marketing: Designing Your Next Marketing Campaign. Boston: Pearson Education.

Li, C., Bernoff, J. (2008). Groundswell: Winning in a World Transformed by Social Technologies. Boston: Harvard Business School Press.

Livingstone, S. (2002). Handbook of New Media. Thousand Oaks; London; New Delhi: Sage. MacNamara, J. e Zerfass, A. (2012). Social Media Communication in Organizations: The challenges of balancing openness, strategy and management. International Communication Association 2012 Conference. Phoenix.

Manovich, L. (2002). The Language of New Media. Cambridge: The MIT Press.

Marktest (2011). Os Portugueses e as Redes Sociais. [online] http://www.marktest.com/ wap/a/n/id 185b.aspx

Marktest (2012). Os Portugueses e as Redes Sociais. [online] http://www.marktest.com/ wap/a/p/id 121.aspx

Maxwell, J. (2005). Qualitative Research Design: An Interactive Approach. Thousand Oaks: Sage Publications.

Mellucci, A. (1999). Acción colectiva, vida cotidiana y democracia. El Colégio de México, 
Micek, D., Micek, J.P. e Whitlock, W. (2009). The Twitter Handbook: How Social Media and Mobile Marketing is Changing the Way We Do Business and Market Online. New York: Morgan James Publishing.

Miller, K. (2009). Organizational Communication: Approaches and Processes. New York: Wadsworth.

Postman, J. (2008). SocialCorp: social media goes corporate. Berkeley: New Riders Press.

Qualman, E. (2009). Socialnomics: How Social Media Transforms the Way We Live and Make Business. New Jersey: John Wiley and Sons.

Rossi, M e Azevedo, R. (2008). Jornalistas e Assessores de Imprensa. São Paulo: Mega Brasil. Scott, D. (2010), The New Rules of PR and Marketing: How to Use Social Media, Blogs, News Releases, Online Video, and Viral Marketing to Reach Buyers Directly, New Jersey: John Wiley \& Sons.

Scherer-Warren, I. (2003) Redes sociais: trajetórias e fronteiras. In Redes, Sociedades e Territórios. Santa Cruz do Sul: EDUNISC

Solis, B. e Breakenridge, D. (2009). Putting the Public back in Public Relations: How social media is reinventing the aging business of public relations. New Jersey: FT Press.

Tapscott, D. (2008). Grown Up Digital: How the Net Generation is Changing Our World. New York: McGraw-Hill.

Tapscott, D. e Williams, A. (2006). Wikinomics: How Mass Collaboration Changes Everything. New York: Penguin Group.

Theaker, A. and Yaxley, H. (2012). The Public Relations Strategic Toolkit: An essential guide to successful public relations practice. London: Routledge.

Toffler, A. (1980). The Third Wave. EUA: Bantam Books.

Touraine A. (2003). Poderemos viver juntos? Iguais e diferentes. Petrópolis: Vozes

Touraine A. (1998) Crítica da modernidade. Petrópolis: Vozes, 1998.

Viana, J. e Ramos, R. (2012). "O Abraço da Adriana ao Sérgio ou a Paz em Tempos de Cólera". I online. [online] http://www.ionline.pt/mundo/abraco-da-adriana-ao-sergioou-paz-tempos-colera

Wilcox, D. e Cameron, D. (2008). Public Relations: Strategies and Tactics. EUA: Allyn \& Bacon. 